\title{
Child Grooming Sebagai Bentuk Pelecehan Seksual Anak Melalui Aplikasi Permainan Daring
}

\author{
Anna Maria Salamor ${ }^{1 *}$, Astuti Nur Fadillah ${ }^{2}$, Patrick Corputty ${ }^{3}$, Yonna Beatrix \\ Salamor ${ }^{4}$ \\ 1, 2, 3, ${ }^{4}$ Fakultas Hukum Universitas Pattimura, Ambon, Indonesia \\ *E-mail: annamariasalamor@gmail.com
}

\begin{tabular}{|c|c|}
\hline Dikirim: 20/07/2020 & Dipublikasi: $25 / 12 / 2020$ \\
\hline Info Artikel & Abstract \\
\hline \multirow[t]{2}{*}{$\begin{array}{l}\text { Keywords: } \\
\text { Chlid; Sexual abuse; } \\
\text { Online. }\end{array}$} & $\begin{array}{l}\text { The rapid development of society and the development of technological } \\
\text { advancements with the use of the internet in addition to having a positive } \\
\text { impact can also have an impact with increasing crime that appears With } \\
\text { a variety of modus operandi based on technological tools that if not } \\
\text { accompanied by the development of knowledge in society about the law } \\
\text { will cause a person to become a criminal or being a victim of a criminal } \\
\text { offense is not uncommon for children to be targeted as victims. One form } \\
\text { of crime that occurs in society is the crime of sexual abuse of children } \\
\text { through the internet so that the development of the rule of law is also } \\
\text { demanded to be able to overcome the development of this problem. This } \\
\text { study aims to assess and analyze whether child grooming can qualify as } \\
\text { a form of sexual abuse against children. The method used in this study } \\
\text { is normative juridical. The results obtained show that child grooming in } \\
\text { Hago games through online media is done with the victim mode being } \\
\text { asked to send photos or videos without using clothes or naked by the } \\
\text { groomer. Groomer builds closeness with the initial mode of asking for } \\
\text { the victim's wa number and establishing closeness, giving rise to } \\
\text { sympathy and empathy so that closeness is established between the } \\
\text { victim and the perpetrator. }\end{array}$ \\
\hline & Abstrak \\
\hline Kata Kunci: & $\begin{array}{l}\text { Kehidupan manusia dalam bentuk bermasyarakat terus mengalami } \\
\text { perubahan dari berbagai aspek, baik yang berdampak terhadap }\end{array}$ \\
\hline $\begin{array}{l}\text { Anak; } \quad \text { Kekerasan } \\
\text { Seksual; Daring. }\end{array}$ & $\begin{array}{l}\text { kemajuan kehidupan tersebut maupun yang berdampak pada } \\
\text { meningkatnya kejahatan dalam hidup manusia. Contoh bentuk } \\
\text { kemajuan terhadap kehidupan manusia adalah kehadiran jaringan dunia } \\
\text { maya (internet) yang dapat diakses oleh siapa saja. Kemajuan ini tentu } \\
\text { memiliki sisi baik dan buruk. Dari sisi baik, kehadiran dunia maya dapat } \\
\text { menghubungkan antara manusia yang satu dengan manusia yang lain } \\
\text { tanpa perlu bertatap muka. Sedangkan dari sisi buruk, kehadiran dunia } \\
\text { maya turut menyumbang munculnya berbagai tindak kejahatan yang } \\
\text { muncul dengan berbagai modus yang memanfaatkan kemajuan } \\
\text { teknologi ini. Jika kehadiran internet tidak ditunjang dengan perangkat }\end{array}$ \\
\hline
\end{tabular}


DOI:

10.47268/sasi.v26i4.381

hukum yang dapat mengakomodir setiap manusia, maka dipastikan banyak orang dapat berpotensi sebagai seorang pelaku kejahahatan maupun sebagai seorang korban kejahatan. Salah satu jenis kejahatan yang memanfaatkan kemajuan jaringan dunia maya adalah pelecehan seksual. Penelitian ini bertujuan unuk mengkaji dan menganalisis apakah child grooming dapat dikualifikasikan sebagai bentuk pelecehan seksual terhadap anak. Metode yang digunakan dalam penelitian ini adalah yuridis normatif. Hasil yang didapat menunjukan bahwa child grooming dalam permainan Hago melalui dengan media daring dilakukan dengan modus korban diminta mengirimkan foto atau video tanpa menggunakan pakaian atau telanjang oleh groomer. Groomer membangun kedekatan dengan modus awal meminta nomor korban dan menjalin kedekatan, menimbulkan simpati dan empati agar terbangun kedekatan antara korban dan pelaku.

\section{A. PENDAHULUAN}

Kehidupan manusia dalam bentuk bermasyarakat terus mengalami perubahan dari berbagai aspek, baik yang berdampak terhadap kemajuan kehidupan tersebut maupun yang berdampak pada meningkatnya kejahatan dalam hidup manusia. Contoh bentuk kemajuan terhadap kehidupan manusia adalah kehadiran jaringan dunia maya (internet) yang dapat diakses oleh siapa saja. Kemajuan ini tentu memiliki sisi baik dan buruk. Dari sisi baik, kehadiran dunia maya dapat menghubungkan antara manusia yang satu dengan manusia yang lain tanpa perlu bertatap muka. Sedangkan dari sisi buruk, kehadiran dunia maya turut menyumbang munculnya berbagai tindak kejahatan yang muncul dengan berbagai modus yang memanfaatkan kemajuan teknologi ini. Jika kehadiran internet tidak ditunjang dengan perangkat hukum yang dapat mengakomodir setiap manusia, maka dipastikan banyak orang dapat berpotensi sebagai seorang pelaku kejahahatan maupun sebagai seorang korban kejahatan. Salah satu jenis kejahatan yang memanfaatkan kemajuan jaringan dunia maya adalah pelecehan seksual. ${ }^{1}$

Pelecehan seksual adalah permasalah yang genting yang dihadapi dalam hidup manusia yang dipenuhi berbagai kemajuan. Pelecehan seksual mengindikasikan dan menggambarkan pada diri seorang manusia tidak memiliki norma-norma yang jelas sehingga kebebeasan dan hak hidup orang lain dilanggar. Pelecehan seksual ialah bentuk kekerasan yang dapat dilakukan oleh siapa saja, dimana saja, dan kapanpun waktunya. Perempuan dan anak adalah orang-orang yang dianggap lemah sehingga sangat berpotensi untuk menjadi korban pelecehan seksual. $^{2}$

Persoalan pelecehan seksual terhadap anak hingga dimasukkan dalam kategori kejahatan kemanusiaan yang harus dicegah dan dihapuskan. Eksploitasi seksual terhadap anak ini selain merupakan perbuatan melanggar hukum, melanggar Konvensi Hak Anak (KHA), juga bertentangan dengan norma agama dan budaya masyarakat beradab. ${ }^{3}$

Bentuk-bentuk pelecehan seksual antara lain:

1 Kurnianingsih, S. (2011). Pelecehan Seksual Terhadap Perempuan di Tempat Kerja. Buletin Psikologi, 11 (2): 116-129, h. 122

2 Purwanti, A., Zalianti, Marzelina. (2018). Strategi Penyelesaian Tindak Kekerasan Seksual Terhadap Perempuan dan Anak Melalui RUU Kekerasan Seksual. Masalah-Masalah Hukum, 47 (2): 138-148, h. 138

3 Syarif, N. (2012), Kekerasan Fisik dan Seksual (Analisis Terhadap Pasal 5 A dan C UU No. 23 Tahun 2004 Ditinjauh Dari Perspektif Hukum Islam). Al- 'ADALAH, 10 (4): 423-434. 
1) Pelecehan seksual verbal adalah bentuk pelecehan Pelecehan seksual yang terjadi secara verbal dapat berupa ucapan ataupun komentar yang mengarah pada topik seksualitas. Perilaku seperti menggoda, menyindir, melempar candaan, bahkan menanyakan hal bersifat seksual terhitung sebagai bentuk pelecehan seksual verbal apabila hal tersebut mampu membuat si korban merasa tidak nyaman.

2) Pelecehan seksual nonverbal yang ditampakkan dari tindakan atau pun gestur seksual yang menimbulkan ketidaknyamanan pada korban. Contoh nyata dari bentuk pelecehan seksual non-verbal ini bisa berupa menggesekkan alat kelamin pada tubuh korban, menunjukkan alat kelamin dan segala bentuk tindakan seksual yang dilakukan pada diri sendiri di hadapan orang lain yang tidak menginginkannya, mengarahkan pandangan pada bagian tubuh seseorang secara seksual, dan segala bentuk gerak-gerik seksual .

3) Pelecehan seksual secara fisik mungkin merupakan bentuk pelecehan seksual yang paling ekstrem, nih! Pelaku pelecehan seksual fisik akan melakukan kontak fisik secara seksual sekalipun korban tidak menginginkannya.Hal-hal seperti pemerkosaan, meraba-raba tubuh korban tanpa izin, memberikan barang pada seseorang dengan harapan memperoleh balasan secara seksual, bahkan melakukan tes keperawanan pada seseorang termasuk ke bentuk pelecehan seksual.Tindakan memeluk, mencium, menepuk, dan membelai ternyata juga dikategorikan sebagai bentuk pelecehan seksual fisik, apabila kamu yang mengalami tidak memberikan izin dan merasa tidak nyaman. ${ }^{4}$

Pelecehan seksual dapat berupa perbuatan meminta, mengomentari Gerakan atau tingkah seseorang yang tidak diinginkan serta dapat dilakukan oleh siapapun. Pelecehan seksual tidak hanya terjadi dalam interaksi tatap muka, tetapi juga dapat ditemukan dalam dunia online ataupun melalui pesan singkat. ${ }^{5}$

Pelecehan seksual dapat terjadi kepada siapa saja salah satu yang sering menjadi korban pelecehan seksual adalah perempuan dan anak. Yang dimaksud anak dalam pengertian ini adalah anak berdasarkan Pasal 1 ayat (1) UU Republik Indonesia Nomor 23 Tahun 2002 tentang Perlindungan Anak adalah : "Anak adalah seseorang yang belum berusia 18 (delapan belas) Tahun, termasuk anak yang masih di dalam kandungan.

Salah satu efek buruk perkembangan di bidang telekomunikasi pada anak adalah dengan mengikutsertakan anak sebagai bagian dari kejahatan yang dilakukan, baik sebagai pelaku maupun korban kejahatan. Tentunya akan berdampak pada mental maupun kehidupan sosial dari anak tersebut. Apalagi jikan kejahatan yang dilakukan berkaitan dengan kejahatankejahatan yang bersifat seksualitas. Bentuk kejahatan (cybercrime) karena perkembangan teknologi komunikasi memiliki dampak negatif yang sangat memprihatinkan bagi anak baik bagi mentalnya hingga ke kehidupan sosialnya. Salah satunya penyalahgunaan kegunaan internet melalui jejaring sosial atau media sosial online oleh oknum-oknum yang tidak bertanggungjawab yang melibatkan anak di bawah umur sebagai korban kekerasan, pelecehan dan pengeksploitasian seksual akibat dari kejahatan seksual. ${ }^{6}$

\footnotetext{
${ }^{4}$ Gadis.co.id Tipe pelecehan seksual. Melalui https://www.gadis.co.id/Ngobrol/3-tipe-pelecehan-seksualyang-perlu-kamu-ketahui-?p=4 (diakses pada 8 Mei 2020).

${ }^{5}$ Tirto.id Modus pelecehan seksual disekolah. Melalui https://tirto.id/modus-modus-pelecehan-seksualdi-sekolah-clpX (diakses pada 10 Mei 2020).

${ }^{6}$ Rofida, Z., Boroya, N., Wati, D. M. (2017), Hubungan antara Kekerasan Seksual dengan Fungsi Seksual Perempuan di Kabupaten Jember, Jurnal Pustaka Kesehatan, 5 (2): 193-198.
} 


\section{B. METODE PENELITIAN}

Penggunaan metode penelitian tulisan ini adalah menggunakan metode penelitian normatif. Suatu metode penelitian hukum yang dilakukan dengan cara meneliti bahan pustaka atau data sekunder sebagai bahan dasar untuk diteliti dengan cara mengadakan penelusuran terhadap peraturan-peraturan dan literatur-literatur yang berkaitan dengan permasalahan yang diteliti. ${ }^{7}$ Data yang dipergunakan adalah data sekunder dengan prioritas pengumpulan bahan hukum sekunder dan bahan hukum tersier. Data yang diperoleh kemudian diolah dan disajikan secara deskritif-analisis.

\section{PEMBAHASAN}

\section{Pelecehan Seksual Terhadap Anak}

Pelecehan atau kekerasan seksual merupakan upaya penyerangan yang bersifat seksual, baik telah terjadi persetubuhan ataupun tidak. Pelecehan atau kekerasan seksual adalah suatu tindakan yang dilakukan oleh seseorang kepada orang lain dengan cara memaksakan keinginan seksualnya dapat disertai dengan ancaman maupun paksaan ${ }^{8}$.

Pelecehan seksual memiliki rentang yang sangat luas, mulai dari ungkapan verbal (komentar, gurauan dan sebagainya) yang jorok atau tidak senonoh, perilaku tidak senonoh (mencolek, meraba, memeluk, dan sebagainya), mempertunjukkan gambar porno atau jorok, serangan dan paksaan yang tidak senonoh seperti, memaksa untuk mencium atau memeluk, bahkan mengancam korban bila menolak memberikan pelayanan seksual, hingga perkosaan. $^{9}$

Pelecehan seksual pada anak adalah suatu bentuk kekerasan dimana seseorang menjadikan anak jalanan untuk melampiaskan rangsangan seksualnya. Perilaku-perilaku pelecehan seksual sudah biasa bagi anak jalanan, seperti anak laki-laki memegang payudara atau paha anak perempuan atau sebaliknya, anak perempuan memegang alat kelamin anak laki-laki.

Anak-anak yang memiliki pengetahuan kurang tentang pendidikan seks akan berisiko tinggi mengalami pelecehan seksual. Mereka menganggap tabu untuk membicarakan halhal yang berkaitan dengan reproduksi, sehingga tidak memiliki gambaran yang tepat tentang pendidikan seks. Usia rata-rata anak jalanan mengalami pelecehan seksual pertama kali yaitu 8-15 tahun. Biasanya pelaku pelecehan seksual adalah sesama anak jalanan. Tempat terjadinya pelecehan seksual dapat di rumah pelaku, pinggir jalan, kolong jembatan, dalam pasar, pinggiran sungai, stasiun, dan dalam angkot. Korban dianggap lemah dan tidak dapat melawan sehingga mendapat perlakuan pelecehan seksual dari pelaku. Berbagai dampak akibat pelecehan seksual dapat dialami korban, seperti perasaan jengkel, takut, menyesal, dan stres, bahkan terkena penyakit menular seksual. ${ }^{10}$

Pelaku pelecehan seksual biasanya akan membujuk korban dengan diiming-imingi sesuatu, misalnya diberi sejumlah uang atau dibelikan barang-barang yang korban inginkan. Bahkan korban ada yang diancam atau dipaksa oleh pelaku. Anak-anak sering menjadi

7 Soekanto, S., Mamudji, S. (2001). Penelitian Hukum Normatif (Suatu Tinjauan Singkat). Jakarta: Rajawali Press, h. 13-14

8 Sumera, M. (2013). "Perbuatan Kekerasan/Pelecehan Seksual Terhadap Perempuan, Jurnal Lex et Societatis, 1 (2): 39-49, h. 43

${ }_{9}$ Gultom, M. (2010). Perlindungan Hukum Terhadap Anak Dalam Sistem Peradilan Pidana Anak di Indonesia. Bandung: Refika Aditama, h. 55

10 Arifah. (2013). Perlindungan Hukum Terhadap Anak Sebagai Korban Pelecehan Seksual. Yogyakarta: Fakultas Syariah dan Hukum Universitas Islam Negeri Sunan Kalijaga, h. 77 
korban karena mereka cenderung tidak berani untuk menolak terutama pada orang yang dikenal. Selain itu, anak-anak mudah sekali untuk dibujuk dengan iming-iming sesuatu. ${ }^{11}$

Saat ini, anak-anak kurang memahami tentang pelecehan seksual dalam berpacaran. Padahal, hal itu tanpa disadari seringkali dialami oleh orang-orang yang berpacaran. Pelecehan seksual dalam berpacaran yang paling sering dialami, antara lain dipaksa berciuman, dipaksa menonton film porno, dipaksa melakukan hubungan seksual. Faktor yang mempengaruhi seseorang mengalami pelecehan seksual adalah gabungan dari faktor korban dan pelaku pelecehan tersebut. Hal tersebut karena mereka masih memiliki pengetahuan yang kurang tentang pelecehan seksual dalam pacaran ${ }^{12}$. Meskipun, korban tahu jika tindakan yang mereka terima dari pacarnya adalah bentuk pelecehan seksual. Namun, korban tidak mampu menolak tindakan pelecehan seksual tersebut karena perasaan takut kehilangan.

Berdasarkan penjelasan mengenai pelecehan seksual diatas terdapat bentuk-bentuk pelecehan seksual dapat dikategorikan menjadi tiga, yaitu: ${ }^{13}$

a) Pelecehan seksual berdasarkan perlakuan yang diterima korban

1) Pelecehan seksual secara non-fisik Pelecehan seksual secara non-fisik meliputi kata-kata menghina, pandangan tidak senonoh, dilihat dari atas ke bawah, pandangan cabul pada bagian-bagian tubuh tertentu, dan ucapanucapan tentang seks. Pelecehan seksual juga dapat berupa korban diajak melihat film porno, diperlihatkan aktifitas seksual secara langsung. Selain itu, pelaku memperlihatkan gambar-gambar porno atau alat kelaminnya pada anak.

2) Pelecehan seksual secara fisik Pelecehan seksual secara fisik dapat berupa pencabulan, sodomi, dan pemerkosaan. Korban pelecehan seksual pada anak yang paling dominan adalah usia di bawah 15 tahun. Lebih luas pelecehan seksual dapat berupa kegiatan, seperti diminta memerankan adegan berbau seks untuk difilmkan, menyentuh dan mencium zona erogen (alat kelamin, bokong, payudara, mulut, paha bagian dalam) anak, meminta atau menyuruh anak untuk menyentuh zona erogen pelaku, pelaku memeluk dan meraba-raba tubuh anak secara tidak wajar, bahkan memaksa anak melakukan hubungan seksual.

b) Pelecehan seksual berdasarkan batasannya

1) Pelecehan seksual ringan sampai sedang Pelecehan seksual kategori ringan sampai sedang antara lain, korban diperlihatkan gambar-gambar porno, diperlihatkan alat kelamin, korban disentuh atau diciumi pada zona erogen atau diminta menyentuh zona erogen pelaku, dipeluk dan diraba-raba secara tidak wajar

2) Pelecehan seksual berat Bentuk pelecehan seksual berat seperti pencabulan, perkosaan per vagina, perdagangan anak19, sodomi (perkosaan per anus).

c) Pelecehan seksual berdasarkan pelakunya

1) Incest Incest merupakan bentuk pelecehan seksual dimana pelaku masih memiliki hubungan darah atau menjadi bagian dalam keluarga inti dengan korban anak, misalnya kakak, adik, paman, ayah kandung maupun ayah tiri. Incest paling rawan terjadi pada anak perempuan.

11 Wahid, A., Irfan, M. (2010). Perlindungan Terhadap Korban Kekerasan Seksual. Bandung: Refika Aditama, h. 99

12 Hilmi, M. F. (2019). Kekerasan Seksual Dalam Hukum Internasional. Jurist-Diction, 2 (6): 2199-2218, h. 2206 .

13 Ahsinin. (2014). Mencegah Dan Menangani Kekerasan Seksual Terhdap Perempuan Dan Anak, Jakarta: Buku Saku, h. 98 
2) Extrafamilial sexual abuse Extrafamilial sexual abuse merupakan pelecehan seksual dimana pelaku bukan anggota keluarga korban atau terjadi di luar lingkungan keluarga korban, misalnya anak sekolah dasar mengalami pelecehan seksual dengan cara disodomi oleh petugas kebersihan di sekolah.

3) Bisnis seks komersial pornografi Bisnis seks komersial pornografi dilakukan oleh suatu jaringan atau mafia pedofilia, dimana anak-anak diburu dan dimanfaatkan untuk kepentingan nafsu menyimpang mereka. Dalam bisnis seks komersial pornografi yang diperdagangkan adalah foto-foto dan video anak-anak telanjang, bahkan beradegan sensual.

Indonesia sekarang terdapat bentuk dan motif terbaru yang digunakan untuk menjerat korban yang masih dibawah umur yaitu dengan menggunakan motif Child grooming. Child grooming merupakan proses mendekati anak dengan tujuan membujuk mereka agar bersedia melakukan aktivitas seksual ${ }^{14}$. Pelaku menggunakan berbagai teknik untuk mengakses dan mengontrol korban. Proses ini membutuhkan akses, waktu, dan keterampilan interpersonal pelaku. Jika child grooming dilakukan dengan baik, korban secara tidak sadar akan mudah 'bekerjasama' dengan pelaku. Semakin mahir keterampilan pelaku dalam memilih dan merayu korban yang rentan, semakin sukses child grooming dilakukan. Keterampilan pelaku mencakup cara memilih korban, mengidentifikasi dan mengetahui kebutuhan korban, waktu yang dibutuhkan oleh pelaku untuk mendekati korban, merayu dan mengendalikan korban. ${ }^{15}$

Dalam menjalankan aksinya pelaku Child grooming sering menggunakan aplikasi game online untuk mendapatkan korban yang masih dibawah umur seperti kasus yang baru-baru ini terjadi di Indonesia, tersangka AAP alias Prasetya Devano alias Defans alias Pras. AAP ditahan polisi karena melakukan tindakan pelecehan anak dengan modus bermain game online 'Hago' Motifnya adalah pelaku bertukar nomor dengan korban selanjutnya pelaku melakukan video call ke korban dan korban disuruh melakukan hal-hal bersifat pornografi dan direkam oleh tersangka. Rekaman itu kemudian digunakan tersangka untuk mengancam korban agar korban mau melakukan aksi serupa itu secara berulang kali.

Selain itu Pelecehan seksual telah diatur dalam peraturan perundangan-undangan di Indonesia untuk meminimalisir perkembangan kejahatan pelecehan seksual. dalam peraturan perundang-undangan di indonesia diistilahkan dengan pencabulan, oleh karena itu pada umumnya diatur dalam Pasal 289 KUHP, yang bunyinya adalah sebagai berikut:

“Barangsiapa dengan kekerasan atau ancaman kekerasan memaksa seseorang untuk melakukan atau membiarkan dilakukan suatu perbuatan cabul, diancam karena melakukan perbuatan yang menyerang kehormatan kesusilaan, diancam dengan pidana paling lama sembilan tahun".

Pelecehan seksual dalam bentuk kekerasan dan ancaman kekerasan untuk bersetubuh dengan anak di bawah umur diatur juga dalam Undang-undang No. 23 Tahun 2002 tentang Perlindungan Anak pada pasal 82 yang menyebutkan:

"Setiap orang yang dengan sengaja melakukan kekerasan atau ancaman kekerasan, memaksa, melakukan tipu muslihat, serangkaian kebohongan, atau membujuk anak untuk melakukan atau membiarkan dilakukan perbuatan cabul, dipidana dengan pidana penjara paling lama 15 (lima belas) tahun dan paling singkat 3 (tiga) tahun dan denda paling banyak Rp. 300.000.000,00 (tiga ratus juta rupiah) dan paling sedikit Rp.

14 Gill, A. K., Harrison, K. (2015). Child Grooming and Sexual Exploitation: Are South Asia Men the UK Media'S New Folk Devils. International Journal for Crime, Justice and Social Democracy, 4 (2): 34-49.

15 Dik-dik, Manshur, M. A., Gultom, E. (2015). Cyber Law: Aspek Hukum Teknologi Informasi. Bandung: Refika Aditama, h. 88 
60.000.000,00 (enam puluh juta rupiah)".

Berdasarkan kedua pasal dari dua undang-undang yang berbeda dapat disimpulkan bahwa tindak pidana pelecehan seksual merupakan suatu perbuatan yang sengaja, yang dilakukan dengan menggunakan kekerasan atau ancaman kekerasan, memaksa, melakukan tipu muslihat, serangkaian kebohongan atau membujuk anak untuk melakukan atau membiarkan dilakukan pelecehan seksual ${ }^{16}$.

\section{Child Grooming Sebagai Bentuk Pelecehan Seksual Terhadap Anak}

Meningkatnya pelecehan seksual terhadap anak terjadi karena adanya kemudahan akses terhadap korbannya, dan teknologi internet mempermudah pelaku mengakses korban untuk melakukan child grooming. Hal ini biasa dikenal dengan online child grooming. Dengan kata lain, online child grooming merupakan proses mendekati anak dengan menggunakan teknologi internet yang bertujuan membujuk mereka untuk bersedia melakukan aktivitas seksual secara online atau offline.

Online child grooming dilakukan dengan berbagai tipe, durasi dan itensitas tergantung dari karakteristik dan perilaku masing-masing pelaku. Diantara berbagai cara dan variasi dalam melakukan online child grooming, terdapat enam hal umum yang mendasari online child grooming yaitu sebagai berikut: ${ }^{17}$

\section{1) Manipulation}

Online child grooming melibatkan beberapa bentuk manipulasi. Terdapat berbagai jenis manipulasi yang dapat dilakukan oleh pelaku terhadap korbannya. Berbagai teknik manipulasi digunakan untuk meningkatkan kekuatan dan kontrol pelaku terhadap korbanserta meningkatkan ketergantungan korban pada pelaku sepertimemberikan pujian untuk membuat korban merasa istimewa. Cara manipulasi ini dilakukan agar korban merasa dicintai dan diperhatikan. Di sisi lain, pelaku dapat mengontrol korban dengan cara mengintimidasi sehingga korban merasa takut dengan pelaku.

2) Accessibility

Kemudahan akses untuk berinteraksi dengan korban menjadi salah satu faktor terjadinya online child grooming. Pelaku dapat mengakses korban melalui internet tanpa harus bertatap muka secara langsung dan tanpa harus membuka identitas aslinya. Dalam dunia nyata, orang tua lebih berwaspada terhadap orang yang berinteraksi langsung dengan anak mereka. Namun, mereka tidak waspada dengan interaksi onlinedan kurang terlibat dalam kehidupan online anak mereka. Menurut penelitian, 20\% anak yang menggunakan jejaring sosial mengatakanpernah berbicara dengan orang asingdi internet dan $20 \%$ diantara mereka berumur 9 hingga 12 tahun. Pelaku memanfaatkan teknologi internet untuk berinteraksi baik satu atau dua arah dengan korbanmelalui chat room, blog, mediasosial, forum atau bulletin.

3) Rapport Building

Sebagai bagian dari membangun hubungan, pelaku melakukan penyesuaian perilaku dan gaya berkomunikasi sehingga membuat korban nyaman berbicara dengan pelaku. Selain itu pelaku mencari tahuketertarikandan keadaan sekeliling korbannya. Agar tindakan yang dilakukan oleh pelaku dengan korban tidak diketahui oleh orang lain, pelaku biasanya meminta korban merahasiakan hubungan mereka.

16 Purandari, T. (2019). Pertanggungjawaban Hukum Pelaku Eksploitasi Seksual Pada Anak Melalui Internet. Media Juris, 2 (2): 233-258, DOI: 10.20473/mi.v2i2.12717, h. 240.

17 Sitompul, A. (2010). Hukum Internet. Bandung: Citra Aditya Bakti, h. 21 


\section{4) Sexual Context}

Hubungan seksual merupakan tujuan online child grooming. Untuk kapan dan bagaimana hubungan seksualitas dimulai tergantung dari masingmasing pelaku. Untuk memulai hubungan seksual dapat dilakukan dengan berbagai macam seperti berbicara jorok, merayu korban, mengirim gambar porno atau menghubungkan ke dalam hal-hal berbau pornografi.

5) Risk Assessment

Penilaian resiko terhadap korban dilakukan sebelum dan pada saat online child grooming. Penilaian resiko dilihat dari beberapa aspek yaitu individu korban, faktor yang berkaitan dengan internet dan lingkungan sekitarnya. Selain itu, pelaku melakukan manajemen resiko. Terdapat tiga cara yang dilakukan oleh pelaku dalam management resiko, yaitu

a) Berhubungan dengan teknologi yang digunakan dan logistik yang terkait dengan pelaku. Sebagai contoh menggunakan beberapa hardware, alamat IP yang berbeda, dan berbagai metode penyimpanan.

b) Pelaku menahan diri berkomunikasi dengan korban di ruang publik dan memilih penggunaan email pribadi atau ponsel.

c) Pelakubertemu dengan korban dengan melakukan pertemuan yang jauh dari lingkungan korban. Namun, ada penelitian yangmengatakan bahwa managemen resiko tidak dimanfaatkan oleh semua pelaku, karena mereka mengganggap tidak melakukan sesuatu yang salah sehingga tidak ada yang perlu disembunyikan.

\section{6) Deception}

Dalam online child grooming, terkadang pelaku menyamar sebagai teman sebaya atau anak muda. Penelitian mencatat bahwa 5\% pelaku menyamar sebagai anak muda ketika berkomunikasi dengan korban. Sebagian besar pelaku memberitahu korban bahwa mereka adalah orang dewasa yangingin membangun hubungan khusus dengan korban. Sebagian besar korban bertemu pelakusecara langsung dan melakukan hubungan seks. Sehingga dapat disimpulkan sebagian besar korban sadar mereka berkomunikasi dengan orang dewasa dan mengambil risiko untuk berinteraksi dengan pelaku.

Jika dilihat dari proses-proses hingga karakteristik Child Grooming maka dapat diartikan bahwa pelaku Child Groooming akan semakin berkembang dengan menggunakan modus-modus terbaru dalam mencari korban seiring dengan kemajuan teknologi yang begitu cepat. Seperti kasus yang baru-baru ini terjadi di Indonesia, tersangka AAP alias Prasetya Devano alias Defans alias Pras. AAP ditahan polisi karena melakukan tindakan pelecehan anak dengan modus bermain game online 'Hago' Motifnya adalah pelaku bertukar nomor dengan korban selanjutnya pelaku melakukan video call ke korban dan korban disuruh melakukan hal-hal bersifat pornografi dan direkam oleh tersangka. Rekaman itu kemudian digunakan tersangka untuk mengancam korban agar korban mau melakukan aksi serupa itu secara berulang kali.

Dalam peraturan perundang-undangan di Indonesia pelaku Child Grooming dapat dijerat dengan Undang-Undang Nomor 19 Tahun 2016 Tentang Perubahan Atas UndangUndang Nomor 11 Tahun 2008 Tentang Informasi dan Transaksi Elektronik, UndangUndang Nomor 35 Tahun 2014 Tentang Perubahan Atas Undang-Undang Nomor 23 Tahun 2002 Tentang Perlindungan Anak dan Undang-Undang No 44 Tahun 2008 Tentang Pornografi. ${ }^{18}$

18 Oktaviani, D. L., Mulyawati, K. R. (2020). Kebijakan Hukum Terhadap Tindak Pidana Child

$$
497 \text { |S A S I Vol. } 26 \text { No.4, Oktober - Desember } 2020
$$


Pasal 27 ayat (1) UU ITE:

"Setiap Orang dengan sengaja dan tanpa hak mendistribusikan dan/atau mentransmisikan dan/atau membuat dapat diaksesnya Informasi Elektronik dan/atau Dokumen Elektronik yang memiliki muatan yang melanggar kesusilaan”.

Pasal 45 ayat (1) UU ITE:

"Setiap orang yang memenuhi unsur sebagaimana dimaksud dalam Pasal 27 ayat (1), ayat (2), ayat (4) dipidana dengan pidana penjara paling lama 6 (enam) tahun dan/atau denda paling banyak Rp 1.000.000.000,00 (satu miliar rupiah)".

Pasal 52 ayat (1) UU ITE

"Dalam hal tindak pidana sebagaimana dimaksud dalam pasal 27 ayat (1) menyangkut kesusilaan atau eksploitasi seksual terhadap anak dikenakan pemberatan sepertiga dari pidana pokok".

Pasal 76 E Undang-Undang Perlindungan anak

"Setiap Orang dilarang melakukan Kekerasan atau ancaman Kekerasan, memaksa, melakukan tipu muslihat, melakukan serangkaian kebohongan, atau membujuk anak untuk melakukan atau membiarkan dilakukan perbuatan cabul".

Pasal 82 UU Perlindungan anak

"Setiap orang yang melanggar ketentuan sebagaimana dimaksud dalam Pasal 76E dipidana dengan pidana penjara paling singkat 5 (lima) tahun dan paling lama 15 (lima belas) tahun dan denda paling banyak Rp5.000.000.000,00 (lima miliar rupiah)".

Pasal 29 UU Pornografi

"Setiap orang yang memproduksi, membuat, memperbanyak, menggadakan, menyebarluaskan, menyiarkan, mengimpor, mengekspor, menawarkan, memperjualbelikan, menyewakan, atau menyediaka pornografi sebagaimana dimaksud dalam pasal 4 ayat (1) dipidana dengan pidana penjara paling singkat 6 (enam) bulan dan paling lama 12 (dua belas) tahun dan/atau pidana denda paling sedikit $\mathrm{Rp} 250.000 .000,00$ (dua ratus lima puluh juta rupiah) dan paling banyak $\mathrm{Rp}$ 6.000.000.000,00 (enam miliar rupiah)".

\section{P E N U T U P}

Berdasarkan uraian diatas maka dapat disimpulkan bahwa child grooming merupakan salah satu bentuk pelecehan seksual anak, yang mana pelecehan seksual itu dilakukan melalui permainan dari yaitu hago. Adapun unsur sengaja serta motif yang tergambar dalam uraian pembahasan menjelaskan bahwa perbuatan yang dilakukan oleh pelaku, dikategorikan sebagai perbuatan pelecehan seksual. Untuk menghindari agar tidak terjadinya pelecehan seksual dengan modus Child Grooming melalui game online maka sebaiknya kepolisian bekerjasama dengan pemilik setiap game online yang mempunyai fitur mengirim foto maupun video call pada aplikasinya untuk dapat menghapus fitur tersebut untuk meminimaisir pelaku pelecehan seksual terhadap anak melalui modus Child grooming.

Grooming. Kertha Wicaksana, 14 (2): 118-123, Doi: 10.22225/kw.14.2.1919.118-123, h. 119

498 | S A S I Vol. 26 No.4, Oktober - Desember 2020 


\section{DAFTAR PUSTAKA}

\section{Jurnal}

[1] Gill, A. K., Harrison, K. (2015). Child Grooming and Sexual Exploitation: Are South Asia Men the UK Media'S New Folk Devils. International Journal for Crime, Justice and Social Democracy, 4 (2): 34-49.

[2] Hilmi, M. F. (2019). Kekerasan Seksual Dalam Hukum Internasional. Jurist-Diction, 2 (6): 2199-2218.

[3] Kurnianingsih, S. (2011). Pelecehan Seksual Terhadap Perempuan di Tempat Kerja. Buletin Psikologi, 11 (2): 116-129.

[4] Oktaviani, D. L., Mulyawati, K. R. (2020). Kebijakan Hukum Terhadap Tindak Pidana Child Grooming. Kertha Wicaksana, 14 (2): 118-123, Doi: 10.22225/kw.14.2.1919.118123.

[5] Purwanti, A., Zalianti, Marzelina. (2018). Strategi Penyelesaian Tindak Kekerasan Seksual Terhadap Perempuan dan Anak Melalui RUU Kekerasan Seksual. MasalahMasalah Hukum, 47 (2): 138-148.

[6] Purandari, T. (2019). Pertanggungjawaban Hukum Pelaku Eksploitasi Seksual Pada Anak Melalui Internet. Media Juris, 2 (2): 233-258, DOI: 10.20473/mi.v2i2.12717.

[7] Rofida, Z., Boroya, N., Wati, D. M. (2017), Hubungan antara Kekerasan Seksual dengan Fungsi Seksual Perempuan di Kabupaten Jember, Jurnal Pustaka Kesehatan, 5 (2): 193 198.

[8] Syarif, N. (2012), Kekerasan Fisik dan Seksual (Analisis Terhadap Pasal 5 A dan C UU No. 23 Tahun 2004 Ditinjauh Dari Perspektif Hukum Islam). Al- 'ADALAH, 10 (4): 423434.

[9] Sumera, M. (2013). Perbuatan Kekerasan/Pelecehan Seksual Terhadap Perempuan. Jurnal Lex et Societatis, 1 (2): 39-49.

\section{Buku}

[10] Ahsini. (2014). Mencegah Dan Menangani Kekerasan Seksual Terhdap Perempuan Dan Anak. Jakarta: Buku Saku

[11] Arifah. (2013). Perlindungan Hukum Terhadap Anak Sebagai Korban Pelecehan Seksual.Yogyakarta: Fakultas Syariah dan Hukum Universitas Islam Negeri Sunan Kalijaga.

[12] Gultom, Maidin. (2010). Perlindungan Hukum Terhadap Anak Dalam Sistem Peradilan Pidana Anak di Indonesia. Bandung: Refika Aditama.

[13] Sitompul, Arsil. (2001). Hukum Internet. Bandung: Citra Aditya Bakti

[14] Soekanto, S, \& Mamudji, S. (2001). Penelitian Hukum Normatif (Suatu Tinjauan Singkat). Jakarta: Rajawali

[15] Wahid, A, \& Irfan, M. (2000). Perlindungan Terhadap Korban Kekerasan Seksual. Bandung: Refika Aditama.

\section{Online/World Wide Web}

[16]Gadis.co.id Tipe pelecehan seksual <https://www.gadis.co.id/Ngobrol/3-tipepelecehan-seksual-yang-perlu-kamu-ketahui-? $\mathrm{p}=4>$.

[17] Tirto.id Modus pelecehan seksual disekolah < https://tirto.id/modus-modus-pelecehanseksual-di-sekolah-clpX>. 